\#ark. Nalarial cachexia and the enfeeblement resulting from Indian service greatly handicap these discharged men in seeking employment in the labour market against healthy men. It is irue more work is done by the officer and the soldier, but the eight-hour day's work of civil life is still hardly dreamed of in the barracks. and so parents resent their boys entering a calling very poorly paid, and which weakens by its routine that derelopment of character that a full day's work produces and on which the future of the nation depends. When people, ignoring all these drawbacks, play the card of "compulsion" I trump it with that of " betterment"- better training, better payment for officers and men, a higher ideal of service and duty to Fngland, and on her part more sympathy with those on whom the "burden of Empire," that most exhausting and enervating strain, weighs with killing force.

In my opinion, at any rate, the army should be a high school for the young men of the land and a trainirg institution raising each individual in it to higher ideals. Education should be fully carried out and the well-chosen officers, well paid and well treated, should live most devotediy for Fngland and she will amply repay them if they care for her sons serving in the army. I say with much pleasure that one corps of officers have never in the past failed in this splendid betterment service. The work done in past years by the medical officers for the "betterment" of the soldier's life has been too devoted for words. Greatly handicapped and weakened by defective status in the past ages of ignorance and neglect they struggled hard and often broke down in the fight for justice for the soldier.

Had their rational, scientific, and common-sense views prevailed in the dark ages of the past army history the defective prestige of the soldier's life that now is dying out so slowly in Fingland would never have existed, and like the police or the post office or any other public national employment a stream of the finest of our young men would with short service be pouring into the service to benefit by its teaching, as the young Dane to-day benefits by the "popular high schools" of that progressive land.

Any medical man who desires to see the soldiers at the "punishment drill" that physically weighs down the young soldier's heart and shakes his circulation has only to halt his carriage any day in front of the railings of Wellington Barracks in London and join in the crowd that day by day looks.on to see the soldier at that old-world "pillory-like" punishment of "defaultery punishment drill," driven about the square by ignorant provost sergeants, and hustled "to make a Roman holiday" in front of a crowd of onlookers. Not all the tinsel glamour and allnremerts of the recruiting sergeants in Trafalgar Square can wipe out the iojurions effects of this wretchedly old-world and public punishment daily going on before the public eye within a stone's throw of the Park. Yet a $6 d$. fine would quite suffice and easily wipe out the offences so punished.

All this, and much more, has to be removed and abolished within the army, and when it is done and betterment comes we shall need no "compulsion." I trust medical men in civil life will inquire into all these matters before becoming conscriptionists. To them I can appeal with confidence because they know the sanitary needs of the military as of the civil population and hard at work themselves can measure by their trying days of duty the easy-going life that otill in certain corps, to the detriment of the nation, survives within the army. I close my letter with these watchwords, "BETTERIENT AND No CONSCRIPTION," and appeal to all medical men to stand by this programme.

$$
\text { I am, Sirs, yours faithfully, }
$$

GEORGE FVATT

Junior United Service Club, London. Surgeon-General late A.M.S.

\section{THE CURRANT AS A FOOD.}

To the Editors of THE LANCET.

SIRS, -The "true inwardness" of the effort which has for some time been made to "boom" the currant as not only an eminently digestible but also as a highly nutritious article of diet would be both amusing and instructive if this were the proper place for exposing it. Mr. J. Cantlie has not at all exaggerated the objections to the currant from the point of view of digestibility. The currant is, of course, only a smail grape, but with a proportionately tougher and less digestible skin than the ordinary grape and with relatively more of it on the well-known principle that the smaller a glonular body is the larger in proportion is the ratio of its surface to its contents.

If we are to recommend any aried form of grape for dietetic use surely it would be more rational to advocate the use of sultana raisins than currants. It is rather an ambiguous recommendation of the currant to say, as $\mathrm{Mr}$. Haydn Brown does, that in bread it will "cause the least harm." As to the preposterons advertisements about the highly nutritive value of currants, until those who are responsible for them can show that the juice of the currant, like that of the grape, contains anything more than a little sugar and a trace of albuminoid and saline matter, it is a mere waste of time to discuss the subject.

I am, Sirs, yours faithfully,

Gloucester, Feb. 23rd, 1907. FRANCIS T. BoND, M.D. Lond.

\section{ON THE CONDITION OF THE BLOOD. VESSELS DURING SHOCK.}

\section{To the Editors of THE LANCET.}

SIRS, - May I be permitted to make a correction in your report in THE LANCET of Feb. 23rd, p. 507, of my remarks in discussing Mr. J. D. Malcolm's paper at a meeting of the Royal Medical and Chirurgical Society on Feb. 12th. The report says that I "did not believe that the treatment of shock by the application of heat was attended by any beneficial result." To have given anyone the impression that such was my opinion I must have been more than usually halting and inconsequent. I am, in truth, quite innocent of heterodox views on the subject of shock and I accepted with all humility the statement that the application of warmth exercises a beneficial influence in the treatment of that condition. Mr. Malcolm had instanced this beneficial influence in favour of his view that the blond-vessels are contracted in shock. What I endeavoured to say in the course of $\mathrm{my}$ criticism of his arguments was that the beneficial influence of warmth was due in all probability partly to its agreeable effect upon the patient and largely to the fact that it tended to prevent undue loss of heat from the surface of the body; and that, further, the action of warmth upon the calibre of the blood-vessels being that of dilatation and the blood-vessels being unduly dilated in shock, such action, if it existed, which I did not believe, would be harmful and not helpful.

That the blood-vessels in shock are dilated and not contracted seemed to me to be abundantly clear from the writings of Crile, Leonard Hill, E. H. Starling, Lockhart Mummery, and others, to whose very convincing arguments Mr. Malcolm's paper had, in my judgment, opposed nothing of any real importance. There are other points on which, judging from the report, my incoherence would seem to have misrepresented me, but inasmuch as they portray me merely as an orthodox platitudinarian bore, and not as a propagandist of dangerous therapeutic heresies, I forbear to trouble you on the subject.

I am, Sirs, yours faithfully,

York-street, W., Feb. 23rd, $1907 . \quad$ LEONARD WILLIAMS.

\section{BURIAL BY THE STATE.}

\section{To the Editors of THE LANCET.}

Sirs,--In The LanceT of Feb. 16th, p. 463, under the above heading, is a letter from Mr. S. P. Wills which, while expressing "wonder that the matter of burial by the State has not been made a subject of practical legislation" and indicating the details over which control is considered desirable, tonches also on the collateral points of premature burial and the "earth-to-earth" and cremation systems of disposal of the dead. That these topics are highly important, intimately bearing on the individual and the community, cannot be questioned; they have already been freely handled in the press, yet no sufficient legislative action has been taken except in the case of cremation, for which necessary safeguards prior to permission to act have been promulgated. The matters tonched upon range themselves under two headings : (1) action desirable on death supervention; and (2) disposal of the body subsequently; and while the efficient control of the former is beyond all doubt the duty of the State, that of the latter, more especially as bearing on one sole mode of burial and its associated details, is open to question. May I say a few words on tile se points?

At the present time we have a condition of affairs which, 